\title{
Multiple Citizenship at Stake: a Critical Assessment of the Croatian Citizenship Policy
} Towards National Minorities

\author{
Nives Mazur-Kumrić, \\ Marie Curie COFUND Postdoctoral Fellow \\ Faculty of Law, University of Liège, Belgium \\ nives.mazurkumric@ulg.ac.be
}

DOI:10.5901/mjss.2014.v5n22p184

\begin{abstract}
The question of (multiple) citizenship of national minorities has been omnipresent in the intellectual and public discourse of the Republic of Croatia since the very beginnings of its independence in the course of early 90s of the 20th century. The transition period of the post-socialism era marked the effort of political elites to establish a balance among the democratic and nationalist concepts of the Croatian statehood, whereat the repercussions of this clash reflected on both the definition of citizenship and the fate of national minorities. With its ethnocentric approach, the Croatian citizenship regime comes out of standard frameworks which define citizenship as a legal bond between the state and an individual, also adding a cultural and political dimension to the nexus in which citizenship frequently becomes an instrument of self-identification with ethnic Croats. The paper aims to shed light on the positioning of national minorities in such social constellations, accentuating the issue of their access to (multiple) citizenship and challenges they face thereof, as well as the inconsistent and selective nature of the Croatian citizenship policy towards different parts of its multi-ethnic corpus. This is primarily done through a concise analysis and interpretation of the Law on Croatian Citizenship - its evolution, core provisions and socio-political circumstances surrounding it. In that vein, the fundamental method used for scientific inquiry is legal dogmatic. The focus of the interest refers to the question to what extent the norms on multiple citizenship accommodate the needs of national minorities, help them preserve their peculiar identities and encourage their wider integration into the Croatian post-transitional society.
\end{abstract}

Key words: multiple citizenship, national minorities, ethnic identity, ethnocentrism, the Republic of Croatia

\section{Introductory Remarks}

The concept of citizenship has been under the spotlight of the legal-political discourse in the contemporary Croatian history since the very beginnings of the Croatian independence. The emphasis needs to be put on the notion 'contemporary' since the origins of the Croatian statehood reach back to the $9^{\text {th }}$ century and during various historical epochs, Croatia has gone through different forms of statehood and political statuses (Macan, 1992; Stančić, 2002). The period preceding the acquisition of recent independence, which is of utmost relevance for our analysis, relates to the 46-year existence of the Socialist Federal Republic of Yugoslavia. In this union, Croatia was one of the six entities which were, despite sharing the same destiny within the same federation, characterized by diverse socio-political circumstances, ethnicities and national identities. The historical heritage of the former state and the consequences of its dissolution have set grounds for the perception of the Croatian approach to the issues of citizenship, including the one concerning multiple citizenship, observed within the context of national minorities. Such linking of citizenship with the rights and status of national minorities in multiethnic societies fairly often moves to the forefront of current legal and political theory (Kymlicka \& Norman, 2000).

The following chapters examine the most peculiar aspects of the Croatian (multiple) citizenship policy with regard to national minorities, seen through the lens of the complex repercussions of the succession of the former Yugoslavia and the closely intertwined quest for national identity. The focus is set on the disputable difference in treatment between ethnic Croats and 'others' when acquiring (multiple) citizenship, legalised by several provisions of the Law on Croatian Citizenship. The respective controversial and widely contested division along ethnic lines appears as the starting point for the central study of the access of national minorities to Croatian citizenship and consequently, to multiple citizenship. Both in theory and practice, the latter issue represents the secondary problem which lies in the shadows of the primary one related to the acquisition of Croatian citizenship in general and the closely interwoven phenomenon of ethnocentrism. Starting from a 
legal analysis of the subject matter, the paper seeks to discuss the wider social arena burden with the past experiences of the coexistence in the multi-ethnic federation, prejudices towards ethnic differences and the wish of the Croatian state to preserve the ethnocentric model of the social order. Summa summarum, the purpose of the paper is to clarify the peculiarities of the Croatian citizenship regime in which not all the national minorities share the same destiny with respect to the access to (multiple) citizenship and its possible benefits.

\section{Yugoslav Legal Heritage as a Basis for the Croatian Concept of Citizenship}

Safeguarding a nation's identity and the fight for independence are deemed as the basic elements of the Croatian historical development (Matković, 1998: 16). What seems to be a curiosity is that Croatia came to be a part of a common state of the South Slavs due to the assumption that these are the nations that share related ethnicities, languages and cultures, or in other words, all those integral elements of identity which served as an instrument of denial of their equality or even similarity during and after the fall of the former Yugoslavia. Along with the idea of 'Yugoslavism' evolved the idea of 'Croatism'. The ratio of the national idea encompassed gathering of all ethnic Croats into one state which, due to a superior ruler - the Habsburg Monarchy, could be achieved only by unification of affiliated neighbouring nations who strived to a similar goal (Goldstein, 2003: 201). However, the creation of one state did not imply generation of one nation. The Yugoslav supraethnic nation constituted only an artificial notion since the nations of the Yugoslav peoples had existed long before the establishment of a common state (Vrcan, 2006: 62-63; Skledar, 1998: 113-119; Ćimić, 1998: 121-133).

While trying to recognize national individualities within the federal state, Yugoslavia was constituted as a federation of equal peoples (hr. narodi) and nationalities (hr. narodnosti). The term of 'peoples' referred to the constitutive nations whose kinstates represented their constituent entities (Bosniaks, Croats, Macedonians, Montenegrins, Serbs and Slovenians) whereas the term of 'nations' entailed national minorities whose national states lay beyond the territory of the former Yugoslavia (e.g. Czechs, Hungarians, Germans, Italians etc.). The breakup of the federation led to the presence of, conditionally speaking, two kinds of national minorities in Croatia - the so-called 'old minorities', i.e. ethnic groups who enjoyed the same minority status prior to the emergence of the independent Croatian state and the 'new minorities', i.e. former constituent peoples in the SFRY. In consequence, this shift brought to substantive changes in the citizenship and civil status of the former constituent peoples which have now become new Croatian minorities. In such circumstances, Croatia had to search for modalities of its citizenship policy which could mitigate or neutralise the negative consequences of political deconstruction. The longing for democracy at the moment of the disintegration of the former federation coincided with the rebirth of extreme nationalism (Buchanan, 2012: 218) which has remained to be a potent social force to this day with significant impacts on the Croatian citizenship policy as one of the tools for additional reinforcement of the positions assumed at the moment of the establishment of new states.

At the present time, the Croatian society can be depicted as bipolar in terms of national identity and citizenship. On one hand, it possesses distinctive national and ethnocentric properties while on the other hand, it reflects a considerable transnational character. The transnational social area is designated by the existence of close cross-border ties and policies of national minorities and their kin-states. Generally speaking, in order to preserve the ethnic ties and particularities of those ethnic collectivities, democratic states are prone to recognise the legitimacy of 'dual loyalty' which gains its legal acknowledgement in the institute of dual/multiple citizenship. As it is shown in the below chapters, Croatia has expressed certain inconsistence and selectiveness regarding this issue. In concreto, it has recognized democratic legitimacy of dual loyalty to a large part of the Croatian ethnic corpus living abroad and hence enabled them to fully participate in the political life of the state (esp. to Croats in Bosnia and Herzegovina) whereas this right has been simultaneously denied or made complicated to members of national minorities who have been present on the Croatian territory for centuries (esp. to Serbs). The status of multiple citizenship is inherent to the Croatian legal tradition. Its predecessor state established the 'nested structure of dual citizenship' (Bauböck, 2000: 368) in which every citizen simultaneously possessed de iure at least two citizenships (Medvedović, 1998): the federal, Yugoslav one, universal for all, and a republic, sub-state one derived from the residence status (Citizenship Act of the Socialist Federal Republic of Yugoslavia, 1976; Citizenship Act of the Socialist Republic of Croatia, 1977). However, de facto republic citizenship was only a formality implying no legal effects within the international community since the republics constituting the federation were no subjects of international law (Komanovics \& Mazur Kumrić, 2011: 358-359). However, this citizenship gained utmost importance at the time of the dissolution of the SFRY when most people were expected to opt for their republic citizenship as a citizenship of their newly emerged states. Moreover, those with previous citizenship of the Socialist Republic of Croatia acquired Croatian citizenship ex lege while all the others became aliens no matter how long they resided on the Croatian territory (Ragazzi, Štiks \& Koska, 2013: 6). The latter, as well as those who inclined to the citizenship of some other republic, could acquire it through the naturalisation procedure, in accordance with the respective citizenship laws. However, in a significant number of cases, disparities in the 
citizenship regimes of successor states made the acquisition of desired citizenships convoluted. It is beyond any doubt that the example of the succession of the former Yugoslavia indicates a plethora of problems and obstacles which could be faced in the process of fragmentation of the citizenship regime of the former state as a consequence of different approaches to acquisition and loss of citizenship in newly established states (Shaw \& Štiks, 2012: 11-12, 22-23). This particularly affected internal Yugoslav migrants who, at the time of the dissolution, resided in the republic whose citizenship they did not possess and had an ethnic background other than the one of the entity's majority population. Furthermore, the additional difficulty was obligatory renouncement of the previous citizenship, which was set as a precondition for acquiring Croatian citizenship, because many overnight aliens in the war-torn region had no access to administrative services necessary for renouncement or issue of a proof of the renouncement. During the Serbian occupation of the Croatian territory, the citizenship status of the Serb minority remained unresolved in occupied areas and it became particularly sensitive and difficult once they fled to neighbouring Serbia and Bosnia and Herzegovina due to the Croatian military takeover. They were de facto Croatian citizens while they resided in the occupied areas, but without 'proving' documents (the so-called domovnica). Once they resettled, they lost a genuine link with Croatia, which led to further aggravation of their chances to acquire Croatian citizenship as Serb refugees/members of the Serbian national minority. Moreover, some of them did not want to embrace the citizenship to which they were entitled (Croatian) and there was no ground for acquisition of the desired one (Serbian). Over the time, they have gradually gained an easier access to Croatian citizenship due to a few normative changes resulting from the Croatian accession to the EU and the correlated harmonisation of national laws with European ones. One of them, the introduction of the new Aliens Act (Aliens Act, 2011) enabled those who had a permanent residence in Croatia on 8 October 1991 and have returned to Croatia, to obtain a permanent residence status necessary for the residence requirement in the procedure of acquiring Croatian citizenship.

\section{Croatian Multiple Citizenship Policy and Its Implications on National Minorities}

Broadly speaking, the Croatian citizenship policy has evolved over two notably distinct periods of time: the nationalistic and ethnically exclusive one from 1991 to 1999 and the more democratic and ethnically inclusive one from 2000 onwards. In the latter period, the predominantly right-wing, overly nationalist political option has been overthrown by considerably liberal and tolerant pro-European parties that have demonstrated a much higher level of inclusiveness towards ethnic minorities and ethnic non-Croats in general, although the citizenship legislation had remained intact until 2011. The norms did not formally change, but their perception and interpretation unquestionably did. This was further facilitated by the enactment of good-quality pro-minority internal legislation, above all, the 2000 Law on Education in Languages and Letters of National Minorities and on the Use of Language and Script of National Minorities, the 2002 Constitutional Act on the Rights of National Minorities and the 2008 Anti-Discrimination Act.

The conditions for acquisition and termination of Croatian citizenship are regulated by the Law on Croatian Citizenship (Law on Croatian Citizenship, 1991, 2011) which has laid firm legal foundations for a stable citizenship regime (Koska, 2012: 195, 207). The Law was adopted during the first wave of codification, on 8 October 1991, i.e. on the day of the succession of the Republic of Croatia, which confirms the utmost relevance of the citizenship issue during succession of states. In the Croatian legal and institutional space, citizenship represents a multilayered and multidimensional notion which transcends a sole legal bond between an individual and the state and steps into the area of national sentiment and pride.

The Law on Croatian Citizenship does not explicitly recognize multiple citizenship and this notion is defined rather ambiguously. Nevertheless, Croatia tolerates it and an access thereto is stipulated by Article 2, Articles $8,8 a, 9,10,11,12$, 15 and 16 (on naturalisation) and Article 21 (on renunciation) of the said Law. Article 2 promotes the principle of exclusivity of Croatian citizenship, emphasising that 'a citizen of the Republic of Croatia who also has foreign citizenship is considered exclusively as a Croatian citizen by the governmental authorities of the Republic of Croatia'. In contradiction to that stipulation, there is a provision of Article $8 \S 1(2)$ enabling a foreigner to obtain Croatian citizenship on the grounds of regular naturalisation, under the condition that he/she has been dismissed from his/her foreign citizenship or that he/she has submitted a proof that he/she will acquire the dismissal if granted Croatian citizenship.

The Law on Croatian Citizenship goes silent on multiple citizenship of national minorities. However, several provisions do have a direct or an indirect effect on their right to acquire multiple citizenship. To assess them, the first step that needs to be taken is to make a distinction between national minorities as potential multiple nationals in Croatia. Namely, these ethnic groups can be viewed from two angles: the external and internal one, i.e. as members of the Croatian national corpus abroad, kin-minorities, on the one hand, and as national minorities on its own territory, on the other hand.

The members of the first group belong to the privileged category of ethnic Croats who are granted a disproportionately easier access to Croatian citizenship in comparison with ethnic non-Croats. The ratio behind this preferential treatment is the intention of the political elites to homogenise the Croatian nation to the greatest possible extent. It is no surprise that in 
such advantageous conditions, a significant portion of Croatian national minorities abroad has opted for multiple citizenship (provided that the country of their residence allows this) and thus additionally preserved genuine links with their kin-state and most elements of their Croatian identity.

As far as the national minorities residing within the national borders are concerned, there are 22 registered ethnic groups, all of them enumerated in the preamble to the Croatian Constitution (Constitution of the Republic of Croatia, 1991, 2010). They are, however, not equally treated à propos the issue of acquisition of (multiple) citizenship. Generally speaking, in order to have the status of a member of a national minority in Croatia, a person needs to be a Croatian citizen (Constitutional Act on the Rights of National Minorities, 2002, Art. 5). Most of these groups have no obstacles to acquire citizenship of another country if its citizenship laws permit multiple citizenship. In that sense, they are treated on the same footing as Croatian citizens of the Croatian ethnicity. It is common and acceptable that they wish to preserve close links with their kinstates through acquiring their citizenships and that act is not contested as a double loyalty phenomenon. Just on the contrary, in such cases, multiple citizenship is regarded as a peculiar legal supplement which enhances standard minority rights protection.

However, due to complex conflicts and post-conflict circumstances, some members of the Serbian and Bosniak minority were put at a disadvantage with members of other national minorities. As noted earlier, they have been facing peculiar obstacles while (re)acquiring Croatian citizenship. Theoretically, there are two provisions of the Law on Croatian Citizenship that might be of use for members of vulnerable Croatian minorities facing problems with the (re)acquisition of Croatian citizenship. Firstly, those who were minors at the time they left Croatia in the course of war and lost Croatian citizenship in accordance with Article 20 (dismissal) and 22 (renouncement) can benefit from Article 23 which stipulates that he/she can acquire Croatian citizenship again if he/she has resided in Croatia for at least twelve consecutive months and if he/she provides a written statement saying that he/she considers him-/herself a Croatian citizen. Secondly, although this could be applicable to probably very few cases, there is another legal ground for these persons to obtain Croatian citizenship (by facilitated naturalisation) - Article 15 relating to a Croatian citizen who has requested and received dismissal from Croatian citizenship in order to acquire foreign citizenship, which was imposed on him/her as a requirement to be able to perform a profession or activity by the foreign state wherein he/she has a domicile. Namely, such a person shall be deemed eligible to acquire Croatian citizenship again if he/she lives in Croatia and has been granted residence despite not meeting all the requirements for regular naturalisation.

To understand the Croatian stance toward multiple citizenship and its ethnocentric policy, a closer look needs to be taken at the naturalisation specificities. The naturalisation procedure is not the same for everyone. The Law makes a clear distinction between regular and facilitated naturalisation. The latter category subsumes aliens who do not need to present a proof of renunciation and refers to those married to a Croatian citizen (Article 10), emigrants (Article 11), those whose citizenship is of interest to Croatia (Article 12), those who were previously Croatian citizens and received dismissal from Croatian citizenship in order to acquire foreign citizenship for professional reasons (Article 15) and ethnic Croats (often members of the Croatian national minority) with no domicile in Croatia (Article 16). However, even this privileged group benefiting from facilitated naturalisation can be divided into subcategories, depending on how many requirements they need to meet to become naturalised citizens.

Article 16 occurs to be one of the most controversial pieces of the Croatian citizenship legislation since it affixes an ethnocentric seal to Croatian citizenship and is very restrictive towards non-ethnic Croats, especially to members of national minorities. The referring provision stipulates that Croatian citizenship may be obtained by a 'member of the Croatian nation' who does not reside in the Republic of Croatia if they meet only one, rather vaguely shaped requirement stated in Article 8 $\S 1$ - that their conduct suggests that they honour the legal order and customs of the Republic of Croatia. By the time, the term of 'member of the Croatian nation' has become disputable as well since the criteria according to which someone can be characterized as such have lost their clarity. The latest amendment of the Law on Croatian Citizenship has been envisaged to put an end to these doubts, so today the scope of the term of 'member of the Croatian nation' involves all those who have earlier declared themselves as such in legal transactions, stated this affiliation in particular public documents, protected the rights and promoted the interests of the Croatian people as well as actively participated in Croatian cultural, scientific and sports associations abroad.

As demonstrated in the above lines, the exclusivity of multiple citizenship has been maintained mostly for the sake of a particular contingency of ethnic Croats living abroad. Such preferential treatment has led to a paradox that many non-ethnic Croats are expected to express exclusive loyalty to the Croatian state by renouncing their previous citizenship during the regular naturalisation procedure, while at the same time, ethnic Croats are free to express multiple loyalties (Koska, 2011: 18). As ethnic Croats are always exempted from renunciation of their current citizenship stipulated by the rules on regular naturalisation, such practice has often been denoted as discriminatory towards ethnic non-Croats. The European Commission against Racism and Intolerance identified members of Roma, Serbian and Bosniak minorities as the most 
vulnerable sections of the Croatian population in that regard (ECRI Report on Croatia, 2012: 10). The same discriminatory attitude toward these three ethnic groups was also noticed in the opinions of the Ministry of Interior who, in line with Article 26 of the Law on Croatian Citizenship, retains a wide margin of discretion while deciding on who should be granted Croatian citizenship (Sajfert, 2013). This particularly affects ethnic Serbs. However, their fate with regard to dual citizenship could have been different. Namely, the idea that the Serbian national minority should be granted dual citizenship is as old as the independent Croatian state. It originates from the European Community's proposal, given within the framework of the International Conference on the Former Yugoslavia held in October 1991, which called for the right to dual citizenship for members of national or ethnic groups who reside in the area with a special status where they constitute the majority population. This right, however, has never been exercised in such manner.

The rules on facilitated naturalisation are not the only provisions of the Law on Croatian Citizenship which make a discriminatory distinction between ethnic Croats and ethnic non-Croats. Namely, Article 30 has induced severe polemics due to its negative repercussions to members of (some) national minorities. It provides that a person is considered a Croatian citizen if he/she has acquired this status pursuant to regulations which had been effective until the day when the Law came into force. However, if a person belongs to the Croatian people but he/she did not have Croatian citizenship on the day when the Law came into force, he/she would be considered to be a Croatian citizen if on that day he/she had a registered domicile in Croatia and provided a written statement saying that he/she considered him-/herself a Croatian citizen.

For better understanding of the generally ambiguous Croatian stance towards its kin-minorities, it is necessary to emphasise that Croatia frequently uses a colloquial expression 'Croatian diaspora' for all the ethnic Croats living abroad, thus making no distinction between migrants and national minorities who are basically two social groups that are subject to a different corpus of legal rules in national and international law (Božić, 1998). This terminological confusion was partly eliminated after the adoption of the Act on the Relations between the Republic of Croatia and Croats Living Abroad (Act on the Relations between the Republic of Croatia and Croats Living Abroad, 2011). This Act differentiates between three groups of Croats living outside their kin-state: members of the sovereign and constituent Croatian nation in Bosnia and Herzegovina, members of the Croatian minority living in European countries and Croatian emigrants living overseas and in European countries and their ancestors (diaspora). It encompasses Croatian people with Croatian citizenship, those having the status of a Croat but not possessing Croatian citizenship and those lacking both elements. They are all considered an equal part of one and inseparable Croatian nation. This status provides them with a number of privileges, for instance they can apply for an accelerated procedure when trying to obtain certain permits such as a temporary residence, work and business permit, they can have a privileged access to particular services and similar, all according to special laws.

The recent amendments to the Law on Croatian Citizenship have not significantly altered the naturalisation procedure. The titulars of regular and facilitated naturalisation have remained the same. Ethnic Croats have retained their preferential status while the conditions for regular naturalisation of ethnic non-Croat foreigners residing in Croatia have tightened. In general terms, the Croatian citizenship policy has remained polarized. On the one hand, it strives to democratise and become more sensitive to ethnic non-Croats through inclusive minority rights legislation, but on the other hand, it keeps preserving its ethno-centric character which favours transnational communities of ethnic Croats (Ragazzi, Štiks \& Koska, 2013: 1-2, 8-9). From the viewpoint of the prism of ethnic identity and multiple citizenship policies, there are two fundamental principles deriving from the Law on Croatian Citizenship: the principle of the legal continuum of republic citizenship and the principle that every member of the Croatian nation (ethnic Croats) shall be regarded as a Croatian citizen (Omejec, 1998).

One of the decisive factors that needs to be taken into account while evaluating the multiple citizenship policy toward national minorities in Croatia is the fact that ethnic sentiments are not equally distributed among all the national minorities, so their identities may appear in a latent or manifest form (Banovac, 1998: 250-251). As a result, not all the minorities are equally interested in acquisition of multiple citizenship. Expectedly, the trend is most prominent among the former constitutive peoples of the Yugoslav federation. The exact figures on the prevalence of dual citizenship among members of national minorities are, however, unknown. The official data on numbers of dual citizens also differ, depending on the source. For example, the benefits of dual citizenship are most widely used by the Croatian kin-minority in Bosnia and Herzegovina, what is evident from the data disclosed by the Croatian Ministry of Interior according to which as many as 678918 applicants possessing Bosnian citizenship were admitted to Croatian citizenship in the period between 1991 and 2010 (Koska, 2013: 220). There is a great disparity between these records and the ones collected by the Croatian Bureau of Statistics in the course of 2011 population census which set the total number of dual citizens in Croatia to only 84885 persons (Stanovništvo s hrvatskim i drugim državljanstvom prema narodnosti, 2011). This vast difference in numbers can be attributed to the reluctance of people to expose their citizenship data in population censuses, the point at issue that could be avoided by introducing a register-based census. 
Even though the Croatian accession to the European Union has had positive effects on making the Croatian citizenship policy softer and more inclusive, it is unlikely to expect a rapid transformation of the present ethnocentric model into a civic one in the near future. This raises curiosities because the inclusive policy towards ethnic Croats living abroad has resulted in a few hundred thousand new EU citizens living outside the EU borders since the Croatian accession in July 2013 (Koska, 2011: 32). To date, the accession has not accelerated the usually correlated trends of the declining importance of the anachronic state boundaries and the increasing importance of post-national or European citizenship (Rosenfeld, 2010: 235242; Howard, 2009: 196-199). Neither did the European Union significantly object to the ethnocentric citizenship standards. It is to assume that one of the main reasons for such a resignation is the usual inclination of states (esp. those prone to ethnocentric laws or stricter citizenship regimes in general) to perceive the notion of citizenship primarily as a matter which to the greatest possible extent falls within the competence of each individual state. Spiro (2011) vividly described this prevalent view with his statement that 'nationality law is the last bastion in the citadel of sovereignty' (p. 746). This autonomy, however, is not absolute and is encompassed by the limitations set by a growing body of international law - international treaties, international custom and general principles of law (Vonk, 2010: 3; Faist, Gerdes \& Rieple, 2004: 914). So far, Croatia has expressed reluctance towards ratification of core international treaties regulating matters of citizenship (International Legal Norms - Croatia, 2014); in fact, it is a party to only two of them: the 1957 Convention on the Nationality of Married Women and the 1999 Convention $n^{\circ} 28$ on the Issue of a Certificate of Nationality. Moreover, it has only signed, but not ratified the 1997 European Convention on Nationality. The respective unwillingness is considered as a direct consequence of the Croatia's ethnocentric policy and the fear that the preferential treatment system established thereof should be modified or abandoned.

\section{Bilateral Agreements on Multiple Citizenship with Neighbouring Countries}

The longstanding aspiration of the Croatian authorities to homogenise the Croatian nation by granting a whole set of privileges to members of kin-minorities and other ethnic Croats abroad, has helped facilitate the improvement of the status and position of some (internal) national minorities in Croatia as well. This has been successfully achieved through conclusion of bilateral agreements on dual citizenship. By now, Croatia has signed and ratified only one respective agreement with Bosnia and Herzegovina and drafted another one with Montenegro. Based on the principle of reciprocity, not only the Croatian kin-minorities in neighbouring states may benefit from such agreements but also the members of the Bosniak and, once/if the dual agreement comes into force, Montenegrin national minorities in Croatia. Taking possible disadvantages of dual citizenship into account, having such agreements is of great importance to legal certainty and transparent interstate relations. This mode of cooperation with other former Yugoslav states tolerating multiple citizenship would unquestionably enhance the rights of their national minorities and improve mutual relations, thus contributing to the preservation of the peculiar multi-ethnic character of the region at large. In addition, in the circumstances of a plural society, multiple citizenship may contribute to softening of the ethnic conception of a nation (Vonk, 2010: 33).

The bilateral agreement on dual citizenship with Bosnia and Herzegovina was signed in 2007 and it came into force in 2012 (Announcement of the Entry into Force of the Dual Citizenship Treaty between the Republic of Croatia and the Republic of Bosnia and Herzegovina, 2012). The willingness of the two states to enable acquisition of dual citizenship was expressed already in 1992 in the bilateral Treaty on Friendship and Cooperation. The Dual Citizenship Treaty provides citizens of the Republic of Croatia and of Bosnia and Herzegovina with the possibility to obtain citizenship of the other contractual party in the fashion and procedure governed by their national legislation. It is based on the principle of mutual respect, integrity, sovereignty and good neighbourly relations. In accordance with general international law rules, a dual citizen is exclusively a citizen of the contractual party on whose territory he/she resides. The Treaty comprises provisions that regulate the traditionally complex issues related to dual citizenship: military obligation, active and passive voting right, diplomatic and consular protection, repatriation from third countries and other (Act on the Ratification of the Citizenship Treaty between the Republic of Croatia and the Republic of Bosnia and Herzegovina, 2007). The holders of the rights stipulated in the treaty are primarily Bosniaks in Croatia, who comprise $0.73 \%$ of the population (Census of Population, Households and Dwellings 2011, 2013: 11), and Croats in Bosnia and Herzegovina, who constituted 17.36\% of the total population in 1991 (Statistički bilten no. 233, 1993: 10). More recent data on the share of the Croatian ethnic group in the total population of Bosnia and Herzegovina are unavailable as the results of the latest census conducted in 2013 have not been published yet.

Croats in Bosnia and Herzegovina are deemed as 'potential Croatian citizens in diaspora' (Štiks \& Ragazzi, 2009: 345) despite their recognition as constituent peoples in their state of residence (Human Rights in Bosnia and Herzegovina, 2009: $411-412,414-416)$. Several aspects of their dual citizenship have been seriously criticized in the past few years. One of 
the most questionable issues is their right to take part in presidential and parliamentary elections in Croatia, which is granted by the Constitution and law (Act on the Election of Representatives to the Croatian Parliament, 1999; Act on the Presidential Elections in the Republic of Croatia, 1992). The Croatian Elections Act foresees a separate election unit for diaspora and a great majority of those votes refer to Bosnian Croats who predominantly vote for right-wing nationally oriented parties (Election of representatives to the Croatian Parliament who are elected by Croatian citizens residing abroad in the $11^{\text {th }}$ electoral unit, 2007). Another controversial aspect of dual citizenship which aroused numerous critiques was linked to the abuse of the extradition procedure for perpetrators of crimes. A large number of convicts, including war criminals, attempted to escape from the country that sentenced them to the country whose citizenship they also possess, (mis)using the national regulations on the prohibition of extradition. However, in order to eradicate misuses of dual citizenship, both states have concluded several agreements on extradition, mutual enforcement of judicial decisions with respect to criminal affairs and prosecution of perpetrators of war crimes, crimes against humanity and genocide ("Overview of bilateral international agreements of the Republic of Croatia", 2014). There is also the persistent problem of returnees of non-ethnic Croats (mainly members of Serbian national minority) who had a residence in Croatia on the day of the proclamation of the Croatian independence, but have acquired Bosnian citizenship in the meantime. Their legal status had not been resolved by the entry into force of the Dual Citizenship Treaty due to different interpretations by the two contractual parties. Namely, Croatia calls upon the ethnically selective Law on Croatian Citizenship whereas the starting point of Bosnia and Herzegovina includes the civil principle which has set grounds for its citizenship act (Sarajlić, 2013: 172).

In 2008, Croatia has launched negotiations on dual citizenship with Montenegro as well. Croatia prepared a draft agreement and Montenegro confirmed its interests, but the drawback is the Montenegrin Citizenship Act that is rigorous concerning dual citizenship granted to citizens of former Yugoslav republics and permits it only in case of possession of residence in Montenegro prior to 3 June 2006, i.e. on the day when Montenegro gained independence ("Do dvojnog državljanstva uz ograničenja", 2012). Therefore, the further course of the negotiations needs to be viewed through the prism of planned amendments to the Montenegrin citizenship legislation. For the time being, the status and preservation of the national, cultural, linguistic and religious identity of the Montenegrin national minority in Croatia, who participate in the total Croatian population with $0.11 \%$ (Census of Population, Households and Dwellings 2011, 2013), and of the Croatian national minority in Montenegro, who make $0.97 \%$ of the Montenegrin population (Population Census 2011, 2014), are regulated by the Agreement on Protection of the Croatian Minority in Montenegro and on Protection of the Montenegrin Minority in Croatia (Agreement on Protection of the Croatian Minority in Montenegro and on Protection of the Montenegrin Minority in Croatia, 2009).

\section{Conclusion}

Over its 23-year long history, Croatia has exposed different sentiments towards different national minorities, which, in turn, has had a direct effect on their unbalanced access to (multiple) citizenship. Those sentiments have ranged from an overly protective attitude towards its external kin-minorities to a discriminatory treatment of some of its internal national minorities (primarily Serbs). Although both sub-groups may be portrayed through the analogous desire to retain close links with both countries: of origin and of residence, and are similarly characterised by the transnational identities of both nations, Croatia has been denying such a reality through its citizenship policy for quite a while. However, due to a solid internal legal framework for the protection of national minorities and the ongoing process of its harmonisation with the EU legislation, it is expected that in the long run these negative aspects will get annulled through ethnically inclusive policy measures.

For the countries that have risen from Yugoslav ashes, acknowledgement of the multiple identities and loyalties of their national minorities through liberal multiple citizenship policies may contribute to the overall stability of the region. In such circumstances, well-defined arrangements on multiple citizenship could be regarded as a special protection instrument of national minorities, which supplements and widens the standard forms of minority protection defined both on national and international level. Population censuses demonstrate that Croatia is becoming increasingly homogenous, so in search for the best modus for the revival of the Croatian multi-ethnic state and harmonic inter-ethnic relations, transparent multiple citizenship policies could be embraced as a significant reconciliatory tool.

\section{References:}

Act on the Election of Representatives to the Croatian Parliament. Official Gazette (116/1999, 109/2000, 53/2003, 69/2003, 19/2007, 20/2009, 145/2010, 24/2011, 93/2011, 120/2011). 
Act on the Presidential Elections in the Republic of Croatia. Official Gazette (22/1992, 42/1992, 71/1997, 69/2004, 99/2004, 44/2006, 24/2011).

Act on the Ratification of the Citizenship Treaty between the Republic of Croatia and the Republic of Bosnia and Herzegovina. Official Gazette - International Treaties (9/2007).

Act on the Relations between the Republic of Croatia and Croats Living Abroad. Official Gazette (124/2011, 15/2012).

Agreement on Protection of the Croatian Minority in Montenegro and on Protection of the Montenegrin Minority in Croatia. Official Gazette - International Treaties (9/2009).

Aliens Act. Official Gazette (130/2011, 74/2013).

Announcement of the Entry into Force of the Dual Citizenship Treaty between the Republic of Croatia and the Republic of Bosnia and Herzegovina. Official Gazette - International Treaties (3/2012).

Anti-Discrimination Act. Official Gazette (85/2008, 112/2012).

Banovac, B. (1998). Etničnost i regionalizam kao izvori identifikacijskih procesa. In R. Čičak-Chand \& J. Kumpes (Eds.), Etničnost, nacija, identitet - Hrvatska i Europa (pp. 249-262). Zagreb: Institut za migracije i narodnosti, Naklada Jesenski i Turk, Hrvatsko sociološko društvo.

Bauböck, R. (2000). Why stay together? A pluralist approach to secession and federation. In W. Kymlicka \& W. Norman (Eds.), Citizenship in diverse societies (pp. 366-394). New York: Oxford University Press.

Božić, S. (1998). Etničnost migrantskih zajednica: nastajanje novih manjina. In R. Čičak-Chand \& J. Kumpes (Eds.), Etničnost, nacija, identitet - Hrvatska i Europa (pp. 85-100). Zagreb: Institut za migracije i narodnosti, Naklada Jesenski i Turk, Hrvatsko sociološko društvo.

Buchanan, T. (2012). Europe's troubled peace: 1945 to the present (2nd $e d$.$) . Malden-Oxford-Chichester: John Wiley \&$ Sons Ltd.

Census of Population, Households and Dwellings 2011, Population by Citizenship, Ethnicity, Religion and Mother Tongue. Zagreb: Croatian Bureau of Statistics, 2013.

Citizenship Act of the Socialist Federal Republic of Yugoslavia. Official Gazette of the SFRY (58/1976).

Citizenship Act of the Socialist Republic of Croatia. Official Gazette (32/1977).

Constitution of the Republic of Croatia. Official Gazette (56/1990, 135/1997, 8/1998, 113/2000, 124/2000, 28/2001, 41/2001, 55/2001, 76/2010, 85/2010).

Constitutional Act on the Rights of National Minorities. Official Gazette (155/2002, 47/2010, 80/2010, 93/2011).

Ćimić, E. (1998). Nacija i religija. In R. Čičak-Chand \& J. Kumpes (Eds.), Etničnost, nacija, identitet - Hrvatska i Europa (pp. 121-133). Zagreb: Institut za migracije i narodnosti, Naklada Jesenski i Turk, Hrvatsko sociološko društvo.

ECRI Report on Croatia (fourth monitoring cycle), European Commission against Racism and Intolerance, CRI(2012)45, adopted on 20 June 2012.

Election of representatives to the Croatian Parliament who are elected by Croatian citizens residing abroad in the $11^{\text {th }}$ electoral unit. Official Gazette (132/2007).

EUDO Observatory on Citizenship. (2014). International Legal Norms - Croatia. Retrieved June 12, 2014, from http://eudocitizenship.eu/databases/international-legal-norms/?search=1\&stype=2\&country=Croatia.

Faist, Th., Gerdes, J. \& Rieple, B. (2004). Dual citizenship as a past-dependent process. The International Migration Review, 38(3), 913-944.

Goldstein, I. (2003). Hrvatska povijest. Zagreb: Novi Liber.

Howard, M. M. (2009). The politics of citizenship in Europe. New York: Cambridge University Press.

Human Rights in Bosnia and Herzegovina in 2008. (2009). Sarajevo: Centar za ljudska prava Univerziteta u Sarajevu.

Komanovics, A. \& Mazur Kumrić, N. (2011). Dual citizenship and ethnic minorities in Hungary and Croatia. In T. Drinóczi \& T. Takács (Eds.). Cross-border and EU legal issues: Hungary-Croatia (pp. 339-369). Pécs-Osijek: Faculty of Law, University of Pécs/Faculty of Law, J. J. Strossmayer University of Osijek. 
Koska, V. (2013). The development of kin-state policies and the Croatian citizenship regime. Minority Studies, 16, 214-230.

Koska, V. (2012). Razumevanje režima državljanstva u okviru složenih trostrukih veza: istraživanje slučaja Hrvatske. In J. Shaw \& I. Štiks (Eds.). Državljani i državljanstvo posle Jugoslavije (pp. 193-218). Beograd: Clio.

Koska, V. (2011). The evolution of the Croatian citizenship regime: from independence to EU integration. Working Paper 2011/15. Florence: The University of Edinburgh, Edinburgh Law School, The Europeanisation of Citizenship in the Successor States of the Former Yugoslavia (CITSEE).

Kymlicka, W., \& Norman, W. (2000). Citizenship in culturally diverse societies: issues, contexts, concepts. In W. Kymlicka \& W. Norman (Eds.), Citizenship in diverse societies (pp. 1-45). New York: Oxford University Press.

Law on Croatian Citizenship. Official Gazette (53/1991, 70/1991, 28/1992, 113/1993, 4/1994, 130/2011).

Law on Education in Languages and Letters of National Minorities. Official Gazette (51/2000, 56/2000).

Law on the Use of Language and Script of National Minorities. Official Gazette (51/2000, 56/2000).

Macan, T. (1992). Povijest hrvatskog naroda. Zagreb: Nakladni zavod Matice hrvatske, Školska knjiga.

Matković, H. (1998). Povijest Jugoslavije (1918.-1991.) - hrvatski pogled. Zagreb: Naklada P.I.P. Pavičić.

Medvedović, D. (1998). Federal and republican citizenship in the former Yugoslavia at the time of its dissolution. Croatian Critical Law Review, 3(1-2), 21-56.

Ministry of Foreign and European Affairs of the Republic of Croatia. (2014). Overview of bilateral international agreements of the Republic of Croatia. Retrieved June 17, 2014, from http://www.mvep.hr/hr/vanjska-politika/bilateralniodnosi/pregled-bilateralnih-medunarodnih-ugovora/bosna-i-hercegovina,17.html.

Omejec, J. (1998). Initial citizenry of the Republic of Croatia at the time of the dissolution of legal ties with the SFRY, and acquisition and termination of Croatian citizenship. Croatian Critical Law Review, 3(1-2), 99-127.

Popis 2011 - Stanovništvo s hrvatskim i drugim državljanstvom prema narodnosti. Obtained for research purposes from the Croatian Bureau of Statistics on March 31, 2014.

Radio Slobodna Europa. (2012). Do dvojnog državljanstva uz ograničenja, 10 January 2012. Retrieved March 27, 2014, from

http://www.slobodnaevropa.org/content/do_dvojnog_drzavljanstva_uz_ogranicenja/24447504.html.

Ragazzi, F., Štiks, I. \& Koska, V. (2013). Report on Croatia. Florence: European University Institute-Robert Schuman Centre for Advanced Studies-EUDO Citizenship Observatory.

Rosenfeld, M. (2010). The identity of the constitutional subject: selfhood, citizenship, culture, and community. AbingdonNew York: Routledge.

Sajfert, J. (2013). Naturalisation procedures for immigrants - Croatia. Florence: European University Institute-Robert Schuman Centre for Advanced Studies-EUDO Citizenship Observatory.

Sarajlić, E. (2013). Multilevel citizenship and the contested statehood of Bosnia and Herzegovina. In W. Maas (Ed.). Multilevel citizenship (pp. 168-183). Philadelphia: University of Pennsylvania Press.

Shaw, J. \& Štiks, I. (2012). Introduction: citizenship in the new South-Eastern European states. In J. Shaw \& I. Štiks (Eds.). Državljani i državljanstvo posle Jugoslavije (pp. 11-33). Beograd: Clio.

Skledar, N. (1998). Religija i etničnost. In R. Čičak-Chand \& J. Kumpes (Eds.), Etničnost, nacija, identitet - Hrvatska i Europa (pp. 113-119). Zagreb: Institut za migracije i narodnosti, Naklada Jesenski i Turk, Hrvatsko sociološko društvo.

Spiro, P. J. (2011). A new international law of citizenship. The American Journal of International Law, 105, 694-746.

Stančić, N. (2002). Hrvatska nacija i nacionalizam u 19. i 20. stoljeću. Zagreb: Barbat.

Statistical Office of Montenegro. (2014). Population Census 2011. Retrieved May 5, 2014, from http://www.monstat.org/cg/page.php?id=534\&pageid=322.

Statistički bilten no. 233 (1993). Popis stanovništva, domaćinstava, stanova i poljoprivrednih gazdinstava 1991 - Republika Bosna i Hercegovina. Sarajevo: Zavod za statistiku Bosne i Hercegovine. 
Štiks, I. \& Ragazzi, F. (2009). Croatian citizenship: from ethnic engineering to inclusiveness. In R. Bauböck, B. Perchinig \& W. Sievers (Eds.), Citizenship policies in the new Europe: expanded and updated edition (pp. 339-363). Amsterdam: Amsterdam University Press.

Vonk, O. (2010). Dual nationality in the European Union. Florence: European University Institute.

Vrcan, S. (2006). Nacija, nacionalizam i moderna država. Zagreb: Golden marketing - Tehnička knjiga. 